УДК 616.8-009.86-053.2

DOI 10.11603/24116-4944.2019.2.10916

\author{
(C). М. Косовська, В. О. Косовська \\ Тернопільсъкий національний медичний університет ілені І. Я. Горбачевсъкого \\ МОЗ України
}

\title{
ВИПАДОК ХВОРОБИ КРАББЕ В ПЕДІАТРИЧНІЙ ПРАКТИЦІ
}

Хвороба Краббе (глобоїдно-клітинна лейкодистрофрія) - швидко прогресуюче демієлінізуюче дегенеративне захворювання центральної нервової системи. Тип успадкування - автосомно-рецесивний. В основі хвороби лежить зниження активності ферменту галактозилцерамід-ß-галактозидази, який в нормі розщеплює галактоцереброзид до цераміду і галактози. Хвороба Краббе викликається мутаціями в гені GALC, який розташований на 14-й хромосомі (14q31). Внаслідок цієї мутації виникає дефіцит ферменту галактозилцерамідази. Залежно від віку, в якому проявилося захворювання, виділяють такі клінічні форми галактозилцерамідного ліпідозу: інфантильну, або класичну (розвиток хвороби починається з 3-6 місяців), пізню інфантильну (з 6-18 місяців), ювенільну, дорослу. Для діагностики використовують біохімічні тести (кров або клітини шкіри), які полягають у визначенні рівня фрерменту галактоцерамідази або у виявленні підвищеного рівня психозину, зниження активності галактозилцерамід-ß-галактозидази.

Специфрічне лікування не розроблено. На сьогодні лікування перебуває в стадії розробки - вчені вивчають можливість доставки Galc-гена в клітини хворого за допомогою вірусів (генна терапія), однак цей метод до кінця не вивчений. На ранніх стадіях захворювання або при повільно прогресуючих фрормах досить есективним методом лікування є трансплантація кісткового мозку, отриманого з клітин пуповинної крові (гемопоетичних стовбурових клітин), яка дозволяє стабілізувати стан хворого і знизити прояви симптомів. У багатьох випадках трансплантація на ранніх етапах приводить до повного виліковування хвороби Краббе.

Дане дослідження проведено на випадку з практики. У дитини діагностовано хворобу Краббе. Оскільки дана патологія належить до спадкових захворювань, єдиною можливою профрілактикою є генетичний аналіз при наявності хвороби Краббе у близьких родичів. Для попередження народження другої дитини з аналогічним захворюванням найбільш раннім методом діагностики є молекулярно-генетичне обстеження (пренатальна діагностика), в процесі якого визначається активність фрерменту галактоцереброзидази та галактозилцерамід- $\beta$-галактозидази в культивованих клітинах амніотичної рідини і ворсин хоріона.

Ключові слова: хвороба Краббе; клінічні ознаки; діагностика; діти.

\section{СЛУЧАЙ БОЛЕЗНИ КРАББЕ В ПЕДИАТРИЧЕСКОЙ ПРАКТИКЕ}

Болезнь Краббе (глобоидно-клеточная лейкодистрофия) - быстро прогрессирующее демиелинизирующее дегенеративное заболевание центральной нервной системы. Тип наследования - аутосомно-рецессивный. В основе болезни лежит снижение активности фрермента галактозилцерамид-ß-галактозидазы, который в норме расщепляет галактоцереброзид к церамиду и галактозе. Болезнь Краббе вызывается мутациями в гене GALC, который расположен на 14-й хромосоме (14q31). В результате этой мутации возникает дефицит фермента галактозилцерамидазы. В зависимости от возраста, в котором проявилось заболевание, выделяют следующие клинические формы галактозилцерамидного липидоза: инсрантильную, или классическую (развитие болезни начинается с 3-6 месяцев), позднюю инсрантильную (с 6-18 месяцев), ювенильную, взрослую. Для диагностики используют биохимические тесты (кровь или клетки кожи), которые заключаются в определении уровня фрермента галактоцерамидазы или в выявлении повышенного уровня психозина, снижения активности галактозилцерамид-ß-галактозидазы.

Специфрическое лечение не разработано. В настоящее время лечение находится в стадии разработки: ученые изучают возможность доставки Galc-гена в клетки больного с помощью вирусов (генная терапия), однако этот метод до конца не изучен. На ранних стадиях заболевания или при медленно прогрессирующих фрормах достаточно эффективным методом лечения является трансплантация костного мозга, полученного из клеток пуповинной крови (гемопоэтических стволовых клеток), которая позволяет стабилизировать состояние больного и снизить проявления симптомов. Во многих случаях трансплантация на ранних этапах приводит к полному излечению болезни Краббе.

Данное исследование проведено на случае из практики. У ребенка диагностирована болезнь Краббе. Поскольку данная патология относится к наследственным заболеваниям, единственной возможной профилактикой является генетический анализ при наличии болезни Краббе у близких родственников. Для предупреждения рождения второго ребенка с аналогичным заболеванием наиболее ранним методом диагностики является молекулярно-генетическое обследование (пренатальная диагностика), в процессе которого определяется активность фермента галактоцереброзидазы и галактозилцерамид- $\beta$ галактозидазы в культивируемых клетках амниотической жидкости и ворсин хориона.

Ключевые слова: болезнь Краббе; клинические признаки; диагностика; дети.

KRABBE DISEASE IN PEDIATRIC PRACTICE

Krabbe disease (globe-cell leukodystrophy) is a rapidly progressive demyelinating degenerative disease of the central nervous system. The type of inheritance is autosomal recessive. At the heart of the disease is a decrease in the activity of the enzyme galactosylceramide- $\beta$-galactosidase, which normally splits galactose cerebroside to ceramide and galactose. Krabbe disease is caused by mutations in the GALC gene, which is located on the 14 chromosome (14q31). This mutation results in a deficiency of the enzyme galactosylceramidase. Depending on the age at which the disease appeared, the following clinical forms of galactosylceramide lipidosis are distinguished: infantile or classical (the development of the disease begins from 3-6 months); 
late infantile (6-18 months); juvenile; adult. For diagnosis use biochemical tests (blood or skin cells), which are to determine the level of the enzyme galactoceramidase or to detect an increased level of psychosine, reducing the activity of galactosylceramide$\beta$-galactosidase.

Specific treatment hasn't been developed. Currently, the treatment is under development - scientists are exploring the possibility of delivery of the Galc-gene to the patient's cells with the help of viruses (gene therapy), but this method has not been fully understood. In the early stages of the disease or in slow-progressing forms, a bone marrow transplant derived from cord blood cells (hematopoietic stem cells) is a very effective method of treatment, which helps to stabilize the patient and reduce symptoms. In many cases, transplantation in the early stages leads to complete cure of Krabbe disease.

This research is a case study. The child was diagnosed with Krabbe disease. Since this pathology is related to hereditary diseases, the only possible prevention is genetic analysis in the presence of Krabbe disease in close relatives. To prevent the birth of a second child with a similar disease and the earliest method of diagnosis is a molecular genetic examination (prenatal diagnosis), in which the activity of the enzyme galactose cerebrosidase and galactosylceramide- $\beta$-galactosidase in cultured cells of amniotic fluid and in cells is determined.

Key words: Krabbe disease; clinical signs; diagnostics; children.

Хвороба Краббе (глобоїдно-клітинна лейкодистрофрія) - швидко прогресуюче демієлінізуюче дегенеративне захворювання центральної нервової системи. Розлад названий на честь данського невролога Кнуда Гаралденсена Краббе (Knud Haraldsen Krabbe).

Тип успадкування - автосомно-рецесивний. В основі хвороби лежить зниження активності ферменту галактозилцерамід- $\beta$-галактозидази, який в нормі розщеплює галактоцереброзид до цераміду і галактози.

Епідеміологія. Хвороба Краббе зустрічається приблизно в 1 особи на 100000 новонароджених. Частіше це захворювання виникає в арабів, які живуть на території Ізраїлю. Хвороба діагностується в 1 дитини на 6000 новонароджених. Порівняно високий рівень захворюваності і серед жителів Скандинавських країн - 1:50 000 [1].

Дослідження. Колишній захисник Бафрфало Біллс - Джим Келлі здійснив основний вклад у дослідження та розповсюдження інфрормації про захворювання. Цим він почав займатися після того, як у 1997 році хворобу Краббе діагностували в його сина Хантера. Проте ці дослідження не допомогли, і Хантер Келлі помер від хвороби у віці 8 років.

Патогенез. Хвороба Краббе викликається мутаціями в гені GALC, який розташований на 14-й хромосомі (14q31). Внаслідок цієї мутації виникає десріцит фрерменту галактозилцерамідази. Накопичення неметаболізованих ліпідів порушує процес утворення захисної мієлінової оболонки нерва (оболонки, яка ізолює більшість нервових клітин, забезпечуючи високу швидкість проведення нервових імпульсів), що, в свою чергу, призводить до дегенерації моторних навичок. Хвороба Краббе входить до групи розладів, відомих під назвою лейкодистрофрії. Захворювання викликане порушенням процесу формування мієліну. У головному мозку, печінці, селезінці, нирках, лейкоцитах, фрібробластах накопичуються галактоцереброзид і його похідне психозин. Кількість останнього підвищується в 10-100 разів, що спричиняє токсичну дію на олігодендрогліальні клітини, які формують мієлінову оболонку. У зонах демієлінізації навколо дрібних кровоносних судин біла речовина містить велику кількість глобоїдних гістіоцитів (макрофагів). Зменшення олігодендрогліальних клітин супроводжується гліозом. Периферичні нерви піддаються аксональній дегенерації 3 накопиченням пінистих гістіоцитів [2].

Залежно від віку, в якому проявилося захворювання, виділяють такі клінічні форми галактозилцерамідного ліпідозу:
- інфрантильну, або класичну (розвиток хвороби починається 3 3-6 місяців);

- пізню інфрантильну (3 6-18 місяців);

- ювенільну;

- дорослу.

Класична фрорма становить 85-90 \% всіх випадків [3]. Основні діагностичні критерії

Інфантильна, або класична, форма - перші клінічні симптоми з'являються на 4-му місяці життя.

Перша стадія. Основні клінічні прояви (до 6 місяців):

- підвищена збудливість (безпричинний крик дитини) і м'язовий гіпертонус (верхні і нижні кінцівки в розігнутому стані, кулаки стиснуті);

- підвищення загальної рухової реакції на звукові подразники;

- невмотивоване періодичне підвищення температури;

- труднощі при вигодовуванні.

На 6-му-8-му місяці життя проявляються порушення психомоторного розвитку, можливі судоми.

Друга стадія. Основні клінічні прояви:

- швидка втрата набутих раніше навичок;

- раптове хаотичне скорочення окремих м'язів (міоклонія);

- наростання м'язового тонусу до судомної пози, при якій спина різко вигнута дугою і опора йде тільки на п'яти і потилицю (опістотонус);

- зниження інтелекту;

- на очному дні - атросрія зорових нервів, при якій знижується реакція зіниць на світло;

- зниження або відсутність сухожильних рефлексів;

- гіпотросрія аж до виснаження (кахексія);

- затримка психомоторного розвитку;

- міоклонічні судоми;

- генералізована рухова реакція на слухові подразники;

- спастичний тетрапарез, підвищення глибоких сухожильних рефлексів;

- перисрерична нейропатія лише в окремих випадках.

При прогресуванні виникають глибокі розумові розлади, млявий тетрапарез, знижуються сухожильні рефрлекси, м'язова гіпертонія змінюється гіпотонією. Хворі помирають у віці від 7 місяців до 3 років.

Третя стадія. Основні клінічні прояви:

- судоми;

- розвиток бульбарно-псевдобульбарного синдрому, 
при якому порушується процес ковтання і вимови звуків, а також спостерігається втрата звучності голосу;

- втрата фрункцій головного мозку [3].

Пізня інфантильна форма:

- ранній розвиток ураження зорового нерва або нерва сітківки, яке при відсутності недоліків органів зору призводить до сліпоти (може бути частковою або повною);

- поступове зниження інтелекту;

- порушення рухових навичок.

Ювенільна і доросла форми:

- зорова агнозія (нездатність впізнавати і класифікувати інформацію, що надходить) або геміанопсія, при якій випадає половина зорового поля;

- спастичні парези та паралічі, які виникають через прогресуючу мозочкову атаксію і невропатію (виявляються в першу чергу при порушеннях ходи) [4].

Діагностика:

1) скарги і анамнез, при якому уточнюють, у якому віці з'явилися перші симптоми, як швидко розвивається хвороба;

2) вивчення сімейного анамнезу, при якому дізнаються, чи спостерігали подібні симптоми хвороби у родичів;

3) загальний огляд (оцінюється м'язовий тонус, вираження сухожильних рефлексів, координація рухів, хода);

4) аналіз спинномозкової рідини (ліквору), при якому оцінюють прозорість і колір рідини, її тиск, кількість глюкози, білка (підвищується в процесі руйнування нейронів), солей хлору [5];

5) біохімічні тести (кров або клітини шкіри), які полягають у визначенні рівня ферменту галактоцерамідази або у виявленні підвищеного рівня психозину, зниження активності галактозилцерамід- $\beta$-галактозидази;

6) КТ, МРТ та ЕНМГ (електронейроміограсрія). На початковій стадії захворювання за допомогою МРТ виявляють ураження підкіркових структур, білої речовини мозочка і пірамідальних трактів. Для пізніх стадій характерні атрофрія великого мозку, ураження задніх відділів стовбура мозку або валика, ураження білої речовини головного мозку в тім'яно-потиличних відділах (рис. 1). ЕНМГ дозволяє виявити знижену швидкість проведення імпульсу по периферичних нервах, а також їх демієлінізацію [6];
7) молекулярно-генетичне обстеження (допускає пренатальну діагностику, в процесі якої досліджують амніотичну рідину - визначають активність галактозилцерамід$\beta$-галактозидази в культивованих клітинах) [7].

Лікування. Специфічне лікування не розроблено. На даний час лікування перебуває в стадії розробки - вчені вивчають можливість доставки Galc-гена в клітини хворого за допомогою вірусів (генна терапія), однак цей метод до кінця не вивчений.

На ранніх стадіях захворювання або при повільно прогресуючих формах досить ефективним методом лікування $€$ трансплантація кісткового мозку, отриманого 3 клітин пуповинної крові (гемопоетичних стовбурових клітин), яка дозволяє стабілізувати стан хворого і знизити прояви симптомів. У багатьох випадках трансплантація на ранніх етапах приводить до повного виліковування хвороби Краббе. Здійснюють симптоматичне лікування, що включає приймання протисудомних препаратів. Одним із важливих заходів для покращення м'язового тонусу та кровообігу є фрізіотерапія [8].

Прогноз несприятливий - при інфантильній формі захворювання летальний результат настає протягом 2-х років. При пізніх фрормах захворювання і повільному прогресуванні хвороби тривалість життя збільшується.

Дане дослідження проведено на випадку з практики. Дівчинка І. віком 13 років, перебувала на стаціонарному лікуванні в КНП «Тернопільська обласна дитяча клінічна лікарня».

Скарги матері: не сидить, не стоїть, не тримає голову, не розмовляє, часті судоми.

Анамнез захворювання: дитина хворіє $з 1$ року 3 місяців, коли вперше з'явилися генералізовані тоніко-клонічні судоми. Неодноразово лікувалась у КНП «ТОДКЛ» з приводу судомного синдрому. Обстежена в Національній спеціалізованій дитячій лікарні «ОХМАТДИТ» МОЗ України.

При об'єктивному обстеженні: загальний стан дитини тяжкий за рахунок неврологічної симптоматики. Шкірні покриви бліді, видимі слизові оболонки блідо-рожеві, чисті. Дівчинка зниженого живлення. Продуктивному контакту не доступна, короткочасно фріксує погляд, але швидко виснажується. Обличчя симетричне, гіпомімія, рот напів-

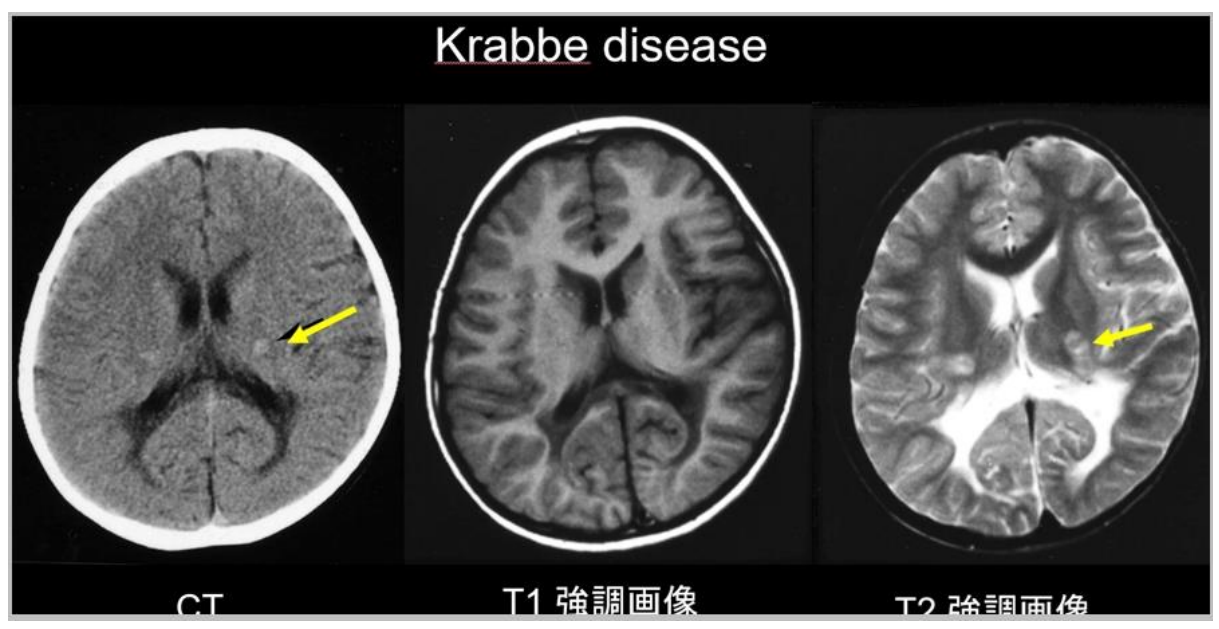

Рис. 1. Комп'ютерна томографрія при хворобі Краббе. Гіперденсна ділянка (стрілка) в задній ніжці внутрішньої капсули (СТ). На Т та $\mathrm{T}_{2}$ аномальні сигнали в задній ніжці внутрішньої капсули (стрілка), білій речовині біля заднього рогу бокового шлуночка і валику мозолистого тіла. 
відкритий, спастична тетраплегія, згинальні контрактури великих суглобів. Не сидить, голову утримує декілька хвилин. Протягом даного періоду наростає руховий і когнітивний десріцит.

Проведено обстеження: загальний аналіз крові: Er. -

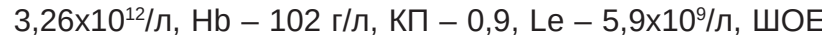
- 10 мм/год, п - $2 \%$, с - $27 \%$, е - 4 \%, л -59\%, м - $8 \%$.

Рентгенограсрія кистей: вимушене положення, десрормація, деконфігурація кісток, деструкція з утворенням порожнин більше в проекції фраланг, виражений остеопороз.

УзД органів черевної порожнини: помірна пієлоектазія справа.

УзД щитоподібної залози - розміщена типово, контури рівні, чіткі, ехогенність збережена, структура однорідна, перешийок 5,0 мм. Права частка - 4,27 см³ (норма 1,76$3,2 \mathrm{~cm}^{3}$ ), ліва - 4,12 см$^{3}$ (норма 1,57-3,06 см³). Загальний об'єм - 8,39 $\mathrm{cm}^{3}\left(3,38-6,24 \mathrm{~cm}^{3}\right)$.

ЕЕГ: значні загальномозкові зміни у вигляді відсутності альфра-ритму, топограф розприділення - виражені зміни кіркової ритміки.

ЕКГ: виражені дисметаболічні зміни міокарда на фоні гіпокальціємії.

Ехо-КС: мінімальний пролапс мітрального клапана, мінімальна недостатність, функція клапана не порушена, ФВ - 74 \%, скоротливість міокарда збережена.

МРТ головного мозку: у середній третині прецентральної звивини і в постцентральній звивині візуалізуються патологічні зони з чіткими нерівними контурами, підвищеної інтенсивності сигналу на $\mathrm{T}_{2}$, Flair і середньої на $\mathrm{T}_{1}$ томограмах. За сигнальними характеристиками виявлені зміни, характерні для демієлінізації. Великий ступінь ураження структур головного мозку відзначається в лівій півкулі. Патологічний процес охоплює субкортикальну білу речовину, поширюється каудально до перивентрикулярних відділів бічних шлуночків. У проекції середньої третини заднього стегна внутрішньої капсули за ходом кортикоспінальних трактів визначаються явища вторинної аксональної дегенерації. Кора прецентральної і постцентральної звивин у проекції уражених ділянок витончена (до 2-3 мм). Візуалізується локальне розширення борозен парацентральних часточок і субарахноїдального простору. Відзначається легке витончення корпусу мозолистого тіла в задніх відділах. Серединні структури не зміщені. Шлуночки звичайної фрорми і розмірів. Зорові нерви симетричні, ретробульбарний простір вільний. Гіпофріз не змінений. Структури задньої черепної ямки, видимі черепно-мозкові нерви, краніоспінальний перехід без особливостей.

Висновок: ураження білої речовини, гліозно-атрофічні зміни в лобно-тім'яних ділянках півкуль мозку.

Рівень гормонів: паратгормон - $326 \mathrm{pg} / \mathrm{ml}$ (норма 15-65), адренокортикотропний гормон - 592,24 pg/ml (норма - 7-63), кортизол - 112,6 нмоль/л (норма ранок - 190-690, вечір - 55-250), ТТГ - 1,77 (норма), дегідроепіандростерон-сульфрат - менше 3 мкг/дл (норма - 22 - 332; діапазон 3-15 000).

Електроліти в крові: кальцій загальний - 1,5 ммоль/л, кальцій (++) - 0,58 ммоль/л, фроссрор - 1,49 ммоль/л, магній - 0,75 ммоль/л, калій - 3,5 ммоль/л, натрій - 139 ммольл.

Клінічний діагноз: прогресуюче дегенеративне захворювання нервової системи (лейкодистрофія Краббе): тетраплегія, розлад психіки і мови, симптоматична епілепсія з частими поліморфними нападами. Первинна хронічна наднирковозалозна недостатність. Соматогенний нанізм. Вторинний гіперпаратиреоз. Дефіцитна анемія змішаного генезу, легкого ступеня тяжкості.

Лікування: преднізолон -2,5 мг × 2 рази на день, кортінефф 5 мг зранку, кальцій $\mathrm{D}_{3}$ нікомед форте $3000 \mathrm{MO}$ на добу, аква $D_{3} 5000$ ОД, карбамазепін 200 мг (1/2 табл.) × 3 рази на день.

ВиснОВки. Хвороба Краббе належать до спадкових захворювань, тому єдиною можливою профрілактикою $€$ генетичний аналіз при виявленні хвороби Краббе у близьких родичів. Хвороба проявляється при наявності десектного гена в обох батьків (ймовірність 1 до 4). При наявності мутації гена GALC в одного з батьків людина $€$ просто носієм дефектного гена.

ПЕРСПЕКТИВИ ПОДАЛЬШИХ ДОСЛІДЖЕНЬ. ДЛЯ попередження народження другої дитини з аналогічним захворюванням найбільш раннім методом діагностики даної патології є молекулярно-генетичне обстеження (пренатальна діагностика), в процесі якого визначається активність ферменту галактоцереброзидази та галактозилцерамід- $\beta$-галактозидази в культивованих клітинах амніотичної рідини і ворсин хоріона.

\section{СПИСОК ЛІТЕРАТУРИ}

1. Темин П. А. Наследственные нарушения нервно-психического развития детей / П. А. Темин, Л. 3. Казанцева. - М. : Медицина, 2001. - 432 с.

2. Suzuki K. Evolving perspective of the pathogenesis of globoid cell leukodystrophy (Krabbe disease) / K. Suzuki // Proc. Japan Acad. - 2003. - N. 1. - P. 1-8.

3. Белоусова Е. Д. Наследственные болезни обмена веществ, проявляющиеся в периоде новорожденности / Е. Д. Белоусова, М. Ю. Никанорова, Е. А. Николаева // Российский вестник перинатологии и педиатрии. - 2000. № 6. - С. 12-19.

4. Wenger, D. A. Molecular genetics of Krabbe disease (globoid cell leukodystrophy): diagnostic and clinical implications / D. A. Wenger, M. A. Rafi, P. Luzi // Hum. Mutat. - 1997. Vol. 10, № 4. - P. 268-279.
5. A case of late variant form of infantile Krabbe disease whith a partial deficiency of galactocerebrosidase / S. Okada, T. Kato, H. Tanaka [et al.]. // Brain Dev. - 1988. - Vol. 10, N. 1. - P. $45-46$.

6. Холин А. В. Магнитно-резонансная томография при заболеваниях центральной нервной системы / А. В. Холин. - СПб. : Гиппократ, 2000. - 192 с.

7. Феничел Дж. М. Педиатрическая неврология : основы клинической диагностики : пер. с англ. / Дж. М. Феничел. М. : Медицина, 2004. - 640 с.

8. Михайлова С. В. Нейрометаболические заболевания у детей и подростков: диагностика и подходы к лечению / С. В. Михайлова, Е. Ю. Захарова, А. С. Петрухин. - М. : Литтерра, 2011. - 352 с. 


\section{Педіатрія}

\section{REFERENCES}

1. Temin, P.A., \& Kazantseva, L.Z. (2001). Nasledstvennye narusheniya nervno-psikhicheskogo razvitiya detey [Hereditary disorders of mental development of children]. Moscow: Meditsina [in Russian].

2. Suzuki, K. (2003). Evolving perspective of the pathogenesis of globoid cell leukodystrophy (Krabbe disease). Proc. Japan Acad, 1, 1-8.

3. Belousova, E.D., Nikanorova, M.Yu., \& Nikolaeva, E.A. (2000). Nasledstvennye bolezni obmena veshchestv, proyavlayuhchesya $v$ periode novorozhdennosti [Hereditary metabolic diseases, manifested in the neonatal period]. Rossiyskiy vestnik perinatologii i pediatrii - Russian Bulletin of Perinatology and Pediatrics, 6, 12-19 [in Russian].

4. Wenger, D.A., Rafi, M.A., \& Luzi, P. (1997). Molecular genetics of Krabbe disease (globoid cell leukodystrophy) diagnostic and clinical implications. Hum. Mutat., 10, 4, 268-279.
5. Okada, S.A., Kato, T., Tanaka, H., Takada, K., \& Aramitsu, Y. (1988). A case of late variant form of infantile Krabbe disease whith a partial deficiency of galactocerebrosidase. Brain Dev., 10, 1, 45-46.

6. Holin, A.V. (2000). Magnitno-rezonansnaya tomografiya pri zabolevaniyakh tsentralnoy nervnoy sistemy [Magnetic resonance imaging in diseases of the central nervous system]. Saint-Petersburg: Gippokrat [in Russian].

7. Fenichel, G.M. (2004). Pediatricheskaya nevrologiya: Osnovy klinicheskoy diagnostiki [Pediatric neurology: Basics of clinical diagnosis]. Moscow: Meditsina [in Russian].

8. Mikhaylova, S.V., Zakharova, E.Yu., \& Petrukhin, A.S. (2011). Neyrometabolicheskie zabolevaniya u detey i podrostkov: diagnostika i podkhody k lecheniyu [Neurometabolic diseases in children and adolescents: diagnosis and treatment approaches]. Moscow: Litterra [in Russian].

Отримано 29.11.19 